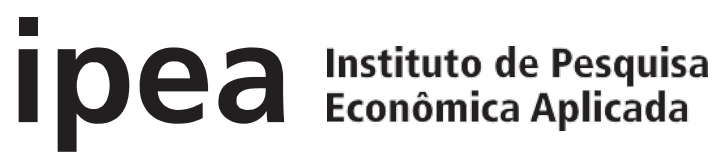

\begin{tabular}{|c|c|}
\hline Título do capítulo & $\begin{array}{l}\text { CAPÍTULO } 6 \\
\text { GOVERNANÇA METROPOLITANA NA COLÔMBIA E SUA } \\
\text { APLICAÇÃO PARA O CASO DO VALE DO ABURRÁ }\end{array}$ \\
\hline Autor(es) & $\begin{array}{l}\text { Julio Miguel Silva Salamanca } \\
\text { Manuel Guillermo Bonilla }\end{array}$ \\
\hline DOI & DOl: http://dx.doi.org/10.38116/978-65-5635-017-2cap6 \\
\hline Título do livro & $\begin{array}{l}\text { Governança Metropolitana na América Latina: um panorama } \\
\text { das experiências contemporâneas sob uma mirada } \\
\text { comparativa }\end{array}$ \\
\hline Organizadores(as) & $\begin{array}{l}\text { Marco Aurélio Costa } \\
\text { Lizandro Lui } \\
\text { Sara Tavares Rebello }\end{array}$ \\
\hline Volume & 4 \\
\hline Série & Governança Metropolitana na América Latina \\
\hline Cidade & Rio de Janeiro \\
\hline Editora & Instituto de Pesquisa Econômica Aplicada (Ipea) \\
\hline Ano & 2021 \\
\hline Edição & $1 a$ \\
\hline ISBN & $978-65-5635-017-2$ \\
\hline DOI & DOI: http://dx.doi.org/10.38116/978-65-5635-017-2 \\
\hline
\end{tabular}

(C) Instituto de Pesquisa Econômica Aplicada - ipea`2020

As publicações do Ipea estão disponíveis para download gratuito nos formatos PDF (todas)

e EPUB (livros e periódicos). Acesse: http://www.ipea.gov.br/portal/publicacoes

As opiniões emitidas nesta publicação são de exclusiva e inteira responsabilidade dos autores, não exprimindo, necessariamente, o ponto de vista do Instituto de Pesquisa Econômica Aplicada ou do Ministério da Economia. É permitida a reprodução deste texto e dos dados nele contidos, desde que citada a fonte. Reproduções para fins comerciais são proibidas. 


\title{
GOVERNANÇA METROPOLITANA NA COLÔMBIA E SUA APLICAÇÃO PARA O CASO DO VALE DO ABURRÁ'
}

\author{
Julio Miguel Silva Salamanca² \\ Manuel Guillermo Bonilla ${ }^{3}$
}

\section{INTRODUÇÃO}

Este documento apresenta os principais elementos de natureza jurídica em torno da constituição das áreas metropolitanas na Colômbia. $\mathrm{Na}$ segunda seção, são descritos, de maneira concisa, a evolução normativa relacionada à constituição da área metropolitana e os requisitos estabelecidos para sua formulação. Posteriormente, o conceito de área metropolitana contido no regulamento atual será exposto, bem como o objeto e a natureza legal desta, a fim de descrever as instâncias dos governos locais nos quais o poder de constituir uma área metropolitana está concentrado.

Em seguida, serão descritos os principais aspectos relacionados ao trabalho de planejamento das áreas metropolitanas, bem como os relacionados à gestão e às respectivas estruturas administrativas adotadas pelo conjunto de áreas metropolitanas estabelecidas na Colômbia. Especificamente, as diretrizes de planejamento formuladas para essas áreas serão examinadas, identificando as funçóes públicas de interesse comum (FPICs) contempladas na estrutura regulatória e desenvolvidas a partir da atual estrutura administrativa.

A seguir, será detalhada a norma relativa às atividades de planejamento e gestáo do território que as áreas metropolitanas devem executar para cumprir o conjunto de objetivos estabelecidos para o seu correto funcionamento. Para isso, serão descritos o conjunto de instrumentos de planejamento e seus respectivos

1. DOI: http://dx.doi.org/10.38116/978-65-5635-017-2cap6

2. Economista pela Universidade Nacional da Colômbia; especialista em formulação e avaliação de políticas e programas públicos nos setores de desenvolvimento urbano, habitação, água potável, saneamento básico, meio ambiente, desastres naturais, competitividade, produtividade e mercados de trabalho; e consultor no âmbito do Programa Executivo de Cooperação Cepal//pea. No setor público na Colômbia, foi vice-ministro de habitação, diretor de desenvolvimento urbano no Departamento Nacional de Planejamento (DNP). E-mail: <jsilva@economiaurbana.com>.

3. Economista pela Universidade Nacional da Colômbia; pesquisador associado da empresa Urban Economy em questões de desenvolvimento urbano e habitação; e consultor da Comissão Econômica para a América Latina e o Caribe (Cepal), da Associação Nacional de Instituiç̧ões Financeiras (Anif), do Banco Interamericano de Desenvolvimento (BID), do DNP, da Cámara Colombiana de la Construcción (Camacol), da Câmara de Comércio de Bogotá e da Secretaria de Desenvolvimento do Distrito Especial de Bogotá. E-mail:<mbonilla@economiaurbana.com>. 
conteúdos, assim como a implementação de tais instrumentos em cada área metropolitana constituída. Entende-se que isso faz parte dos poderes que a lei concede às áreas metropolitanas e dos desenvolvimentos autônomos que cada uma delas adota.

Em seguida, serão descritas as competências dos órgãos de administração em relaçáo ao desenvolvimento metropolitano, a natureza da estrutura administrativa das áreas metropolitanas será analisada e, como um todo, será observada sua estrutura institucional em vigor.

Também será dada ênfase à maneira pela qual funcionam as instâncias de participação no processo de planejamento e desenvolvimento das áreas metropolitanas, mais particularmente a maneira como os municípios pertencentes a essas áreas participam da gestão das diferentes dimensóes do planejamento para o desenvolvimento metropolitano. Da mesma forma, serão investigados os diferentes níveis de participação dos principais atores metropolitanos (governos locais, associações empresariais, empresas autônomas regionais, sociedade civil e outras formas de organizaçáo social). $\mathrm{O}$ relacionamento entre o governo nacional (central) e os governos subnacionais em torno do suporte técnico em gerenciamento e planejamento fará parte do desenvolvimento deste texto.

Por fim, a análise das diferentes opçóes de financiamento para as áreas metropolitanas está contida na Lei no 1.625 , de 2013, que emite o regime que pode ser validado com as evidências apresentadas por cada área metropolitana sobre as fontes de financiamento. Também será analisada a opção de financiamento privado para projetos metropolitanos, bem como os mecanismos, contemplados na Lei da Associação Público-Privada, que permitem o financiamento privado de projetos adequados ao desenvolvimento metropolitano.

\section{PRINCIPAIS ELEMENTOS DE NATUREZA JURÍDICA EM TORNO DA CONSTITUIÇÃO DAS ÁREAS METROPOLITANAS DA COLÔMBIA}

Um ponto de partida de referência para a análise da evolução da organização político-administrativa do Estado colombiano é a Constituição Política de 1886. Como aspecto central da ordem administrativa do território nacional, a Constituição de 1886 concedeu independência aos departamentos ${ }^{4}$ para a administração de assuntos próprios. Além disso, conferiu-lhes o poder de exercer supervisão administrativa sobre os municípios para planejar e coordenar o desenvolvimento regional e local, assim como a prestação de serviços.

4. Os departamentos são regiões administrativas da Colômbia - algo semelhante aos estados brasileiros, porém sem autonomia política e administrativa, tendo em vista que a Colômbia é um país unitário, e não uma federação. 
Com a nomeação que o presidente faria dos governadores e estes últimos para os prefeitos, configurou-se a centralização do poder público, ou seja, o fortalecimento dos poderes do Executivo. Nesta ordem constitucional, a formulação de associaçốes territoriais era altamente improvável.

Oitenta e dois anos depois, a primeira reforma da Constituição Política de 1886 ocorreria por meio do Ato Legislativo no 1, de 1968, nos aspectos relacionados à ordenação da administração departamental e municipal.

O Ato Legislativo no 1 , de 1986, manteve a independência dos departamentos para a administração de assuntos seccionais, bem como o poder de exercer sobre os municípios a proteção administrativa necessária para planejar e coordenar o desenvolvimento regional e local. Nesse ato legislativo, foi introduzida a possibilidade de estabelecer várias categorias de municípios de acordo com população, recursos fiscais e importância econômica, e indicar diferentes regimes de administração, nos termos a seguir.

Para a melhor administração ou prestação de serviços públicos de dois ou mais municípios do mesmo departamento, cujas relaçôes dão as características de uma regiáo metropolitana como um todo, a lei pode organizá-las como tal, sob autoridades e regime especiais, com seu próprio status legal, garantindo uma participação adequada das autoridades municipais na referida organização.

Corresponde às assembleias, por iniciativa do governador, e ouvida anteriormente a opinião dos conselhos dos municípios interessados, para ordenar o funcionamento das entidades assim autorizadas. A lei estabelecerá as condiçóes e normas sob as quais os municípios podem se associar para a prestação de serviços públicos. As assembleias, por iniciativa do governador, podem tornar obrigatória essa associação, de acordo com a lei mencionada, quando a prestaçáo de serviços mais eficiente e econômica o exigir (Colombia, 1968, tradução nossa).

Conclui-se, entáo, que o Ato Legislativo no 1, de 1968, foi o primeiro a declarar a existência de áreas metropolitanas como resultado da organização de dois ou mais municípios, com o objetivo principal de melhorar a administração ou prestação de serviços públicos.

Em 1979, foi emitido o Decreto-Lei no 3.104, no qual, pela primeira vez na história das regulamentaçóes contemporâneas sobre o uso do solo, foi estabelecido um conjunto completo de regulamentaçôes para as áreas metropolitanas, ditando as regras para sua organização e operação, bem como as disposiçôes sobre financiamento. Em particular, os requisitos foram estabelecidos para que dois ou mais municípios do mesmo departamento pudessem ser constituídos em uma área metropolitana, conforme descrito a seguir.

1) De acordo com o conceito do Departamento Nacional de Planejamento, os vários municípios que constituem uma unidade territorial e existem 
relaçóes físicas, demográficas, econômicas, sociais e culturais estreitas que requerem seu desenvolvimento integrado e a melhor prestação de serviços públicos.

2) Que o conjunto de municípios tenha uma população não inferior a 300 mil habitantes e que a população do município principal não seja inferior a 250 mil habitantes, de acordo com a certificação emitida a esse respeito pelo Departamento Administrativo Nacional de Estatística (Dane), com base em projeçôes populacionais na data de emissão da mesma certificação (Colombia, 1979).

O Decreto-Lei no 3.104 , de 1979, estabeleceu que a administração da região metropolitana ficaria a cargo de um conselho e de um prefeito metropolitano. Da mesma forma, decretou para as áreas metropolitanas as funçóes de planejamento, prestação de serviços públicos, e aquelas relacionadas à contribuição de valorização, coordenação administrativa e política fiscal.

No planejamento, destacam-se a formulação e a adoção do PIDM para a regiáo metropolitana e o correspondente programa de investimentos setoriais - e, talvez, o mais importante no planejamento urbano: emitir a regulamentaçáo do uso do solo urbano e rural na área e estabelecer os mecanismos e instrumentos de regulamentação e controle que possam ser usados pelas autoridades da área metropolitana ou dos municípios que a compóem. A adoçáo do plano viário e dos planos diretores de serviço público para a área também estaria entre as principais funçóes.

A medida mais significativa adotada pelo decreto foi a autorização para operar nas áreas metropolitanas, cujo principal núcleo eram os municípios de Medellín, Cali, Barranquilla, Bucaramanga e Pereira, desde que as duas condiçóes indicadas fossem atendidas. $\mathrm{O}$ conceito positivo do DNP tem como exigência que o conjunto de municípios apresente uma população não inferior a 300 mil habitantes e que a população do município principal não seja inferior a 250 mil habitantes.

Em seguida, com a emissão do Código do Regime Municipal contido no Decreto-Lei no 1.333, de 1986, foram ratificadas as disposiçóes do Decreto $\mathrm{n}^{\circ}$ 3.104, de 1979, relativas ao funcionamento, às exigências e às funçóes do conselho metropolitano. ${ }^{5}$

O escopo mais importante do Decreto-Lei oㅜ 1.333, de 1986, foi propor os meios para a sustentabilidade financeira, indicando, a fim de fornecer às áreas metropolitanas, recursos permanentes que lhes permitissem participar dos diversos programas em favor dos municípios integrantes - uma sobretaxa de 1 por $1 \mathrm{mil}$

5. Do original, junta metropolitana. 
$(0,1 \%)$ na avaliação cadastral das propriedades localizadas na jurisdição de cada área, que poderia ser aumentada para um limite máximo de 2 por 2 mil (0,2\%).

A nova Constituição Política de 1991 declarou a Colômbia como um Estado organizado na forma de uma república unitária, descentralizada e com autonomia de suas entidades territoriais. Estabeleceu, assim, os departamentos, os distritos, os municípios e os territórios indígenas, entidades que mais tarde gozariam de autonomia para administrar seus interesses e dentro dos limites da Constituição e da lei. Agora, corresponderia ao município como entidade fundamental da divisão político-administrativa do Estado prestar serviços públicos e ordenar o desenvolvimento de seu território.

A Constituição de 1991 ratificaria que

quando dois ou mais municípios mantêm relaçôes econômicas, sociais e físicas, que dáo todas as características de uma área metropolitana, eles podem se organizar como uma entidade administrativa encarregada de programar e coordenar o desenvolvimento harmonioso e integrado do território colocado sob sua autoridade (Colombia, 1991, tradução nossa).

De acordo com a Constituição de 1991, corresponderia à Lei Orgânica da Ordenação Territorial

adotar para as áreas metropolitanas um regime administrativo e fiscal especial; garantir a participaçáo adequada das respectivas autoridades municipais; e indicar a maneira de convocar e realizar consultas populares que decidem o vínculo dos municípios. Assim, uma vez concluída a consulta popular, os respectivos prefeitos e conselhos municipais irão protocolar a formação da área e definirão seus poderes, financiamento e autoridades, de acordo com a lei (Colombia, 1991, tradução nossa).

$\mathrm{Na}$ ausência de uma lei orgânica de ordenamento territorial, em 1994 foi emitida a Lei no 128 - Lei Orgânica das Áreas Metropolitanas -, mantendo o objeto, a jurisdição e a natureza jurídica das áreas, mas introduzindo novos requisitos para sua constituição, como o fato de motivar a constituição das áreas metropolitanas pelos promotores. Caberia ao secretário convocar uma consulta popular ao texto do projeto de Constituiçáo, entendido como aprovado pelo voto afirmativo da maioria dos votantes.

Em 2013, foi emitida a Lei no 1.625 , de 2013, para o regimento de áreas metropolitanas, revogando a Lei Orgânica no 128, de 1994. Essa lei é a que atualmente regula a criação de áreas metropolitanas e estabelece a validade do objeto, da natureza, dos poderes e das funçóes das áreas metropolitanas, definindo as características integradoras dos municípios que a compóem, conforme podemos ver a seguir. 
As áreas metropolitanas são entidades administrativas de direito público, compostas por um conjunto de dois ou mais municípios integrados ao redor de um município central, interligados por dinâmicas e inter-relaçóes territoriais, ambientais, econômicas, sociais, demográficas, culturais e tecnológicas que, para a programação e coordenação de seu desenvolvimento sustentável, desenvolvimento humano, ordenamento territorial e prestação racional de serviços públicos requerem uma administração coordenada (Colombia, 2013, tradução nossa).

A Lei $\mathrm{n}^{\mathrm{o}}$ 1.625, de 2013, define as condições para a constituição das áreas metropolitanas e a relação com os municípios-membros, nos seguintes termos:

a) terão iniciativa para promover a sua criação os prefeitos dos municípios interessados, um terço dos vereadores dos referidos municípios, 5\% dos cidadãos que compóem o censo eleitoral totalizado dos mesmos municípios e os governadores dos departamentos aos quais pertencem os municípios que pretendem integrar uma área metropolitana;

b) os promotores da região metropolitana elaborarão o projeto de constituição onde for requerido, no mínimo: os municípios que o compóem, o município central e os motivos que justificam sua criação;

\section{(...)}

e) o projeto submetido à consulta popular será considerado aprovado quando a maioria dos votos de cada um dos municípios interessados for favorável à proposta e a participação do cidadáo atingir pelo menos um quarto da populaçáo registrada no respectivo censo eleitoral de cada um dos municípios participantes;

f) concluída a consulta popular, em cada um dos municípios onde o projeto foi aprovado, os respectivos prefeitos e presidentes dos conselhos municipais formalizarão a formação da região metropolitana ou a entrada em uma já existente dentro de um período náo superior a trinta dias corridos (Colombia, 2013, tradução nossa). 
FIGURA 1

\section{Cronologia da expedição de normas sobre áreas metropolitanas}

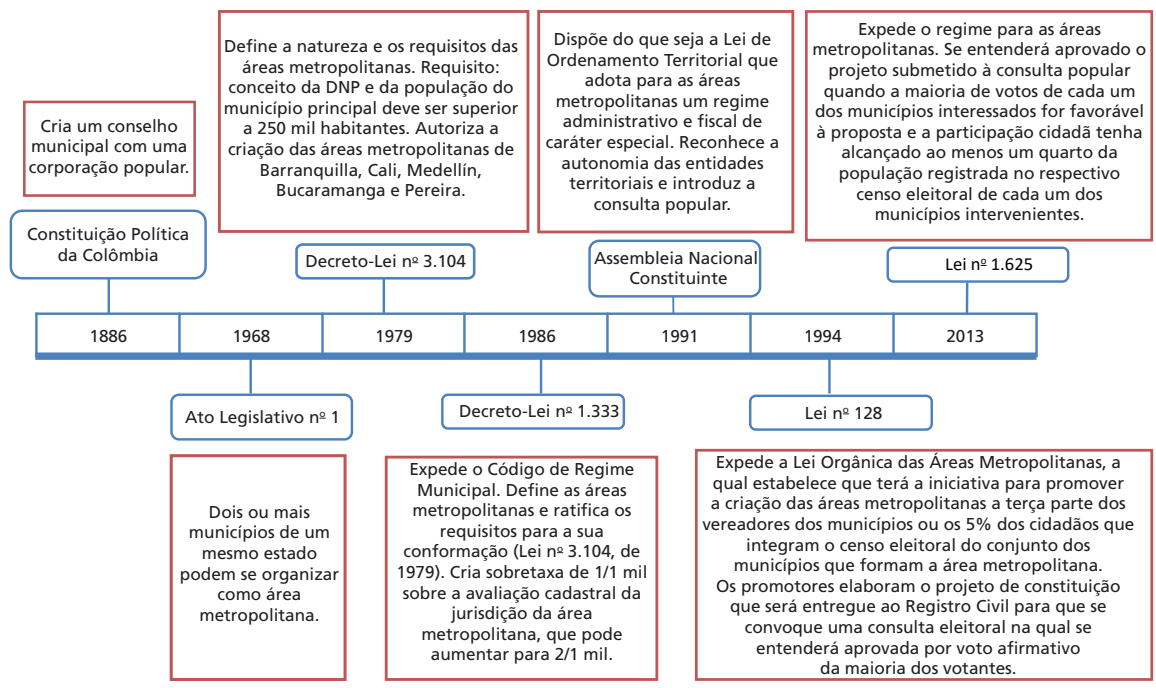

Elaboração dos autores.

\subsection{Diretrizes para o planejamento nas áreas metropolitanas}

A Lei $\mathrm{n}^{\mathrm{o}}$ 1.625, de 2013, culminou com um longo processo de redação de regulamentos que moldou a constituição de áreas metropolitanas na Colômbia. Essa lei estabelece claramente as competências dessas áreas, relacionadas à capacidade de influenciar tanto o desenvolvimento dos municípios que a compóem como o ordenamento do território.

Entre as competências mais importantes sobre o território colocado sob a jurisdição das áreas metropolitanas estão: i) programar e coordenar o desenvolvimento harmonioso, integrado e sustentável dos municípios que a compóem; ii) racionalizar a prestação de serviços públicos pelos municípios que a compóem; iii) executar obras de infraestrutura viária e desenvolver projetos de interesse social na região metropolitana; e iv) estabelecer diretrizes e orientaçóes específicas para o planejamento do território dos municípios que a compóem.

$\mathrm{E}$, de acordo com os poderes mencionados anteriormente, a lei estabelece as funçóes das áreas metropolitanas, nas quais suas principais execuçóes se relacionam:

- ao planejamento do desenvolvimento;

- ao ordenamento territorial;

- $\quad$ à formulação de políticas habitacionais; 
- à gestáo de serviços públicos terrestres e metropolitanos;

- à execução de obras metropolitanas;

- à formulação de políticas regionais de mobilidade;

- ao exercício da função de autoridade de transporte público; e

- à adoção de instrumentos de planejamento e desenvolvimento de transporte metropolitano.

A principal função orbitará em torno da capacidade de contribuir para o planejamento do uso do solo, definindo e regulamentando o que seria designado como fatos metropolitanos, incluídas a formulação e a adoção do Plano Integral de Desenvolvimento Metropolitano (PIDM), com ênfase no componente de planejamento físico territorial como padrão obrigatório aos municípios que compóem a área metropolitana.

Com relação aos poderes para planejar o desenvolvimento do território, a Lei $\mathrm{n}^{\mathrm{o}} 1.625$ estabelece que as áreas metropolitanas identificam os fatos metropolitanos para que, consequentemente, sejam formulados o PIDM e o Plano Estratégico Metropolitano de Ordenamento Territorial (Pemot). A mesma lei propóe as definiçóes elencadas a seguir.

1) Fatos metropolitanos são aqueles fenômenos econômicos, sociais, tecnológicos, ambientais, físicos, culturais, territoriais, políticos ou administrativos que afetam ou impactam simultaneamente dois ou mais dos municípios que compóem a região metropolitana.

2) Planos abrangentes de desenvolvimento metropolitano são uma estrutura estratégica geral de longo prazo, com uma visão metropolitana e regional integrada que permite a implementação de um sistema de coordenação, direção e programação do desenvolvimento metropolitano e estabelece critérios e objetivos comuns para o desenvolvimento sustentável dos municípios em sua jurisdição. Esse marco constitui uma norma de hierarquia mais alta e é decisivo para os planos de ordenamento territorial (POTs), planos de desenvolvimento e outros instrumentos de planejamento em relação aos fatos metropolitanos.

3) O Pemot deve conter pelo menos o seguinte, dependendo do modelo de uso do solo: i) definição da estratégia e do sistema de gerenciamento integral da água (coleta, armazenamento, distribuição e tratamento); ii) definição do sistema metropolitano de vias e transporte público urbano (coletivo, misto, maciço, tipo táxi individual); iii) definição do sistema metropolitano de equipamentos; iv) dimensionamento e definição da estratégia de habitaçáo social e prioritária na região 
metropolitana e dos instrumentos de gestão fundiária destinados a esse fim; e v) gestão de terras rurais e suburbanas.

4) Por sua vez, a formulação do PIDM é composta por: i) definição da visão, da missão e dos objetivos em relação aos fatos metropolitanos e aos poderes concedidos às áreas metropolitanas, bem como políticas, estratégias, programas e projetos por meio dos quais esses objetivos seráo alcançados; ii) definição de metas destinadas a alcançar os objetivos e os indicadores que avaliam a gestão do PIDM, com periodicidade mínima de quatro anos; iii) instituição de diretrizes para a localização da infraestrutura de transporte, serviços públicos, equipamentos e espaços públicos em escala metropolitana; iv) definição de áreas de reserva para a proteção de meio ambiente, recursos naturais e paisagem, determinação de áreas estratégicas suscetíveis de serem declaradas como áreas protegidas e estabelecimento de diretrizes para sua execução ou operação, quando definidas como fatos metropolitanos; v) diretrizes físico-territoriais, sociais, econômicas e ambientais relacionadas aos fatos metropolitanos; vi) determinação da estrutura urbano-rural para horizontes de médio e longo prazo; vi) instituição de políticas, estratégias e diretrizes para a localização de programas e projetos de habitação de interesse social em escala metropolitana; e vii) estabelecimento de mecanismos que garantam a distribuição equitativa de encargos e benefícios, gerados pelas regulamentaçôes territoriais e ambientais (Área Metropolitana del Valle de Aburrá, 2007).

A Lei no 1.625 , de 2013, além de formular instrumentos de planejamento territorial, avançou na definição dos órgãos de gestão e administração das áreas metropolitanas. Nesse caso, definiu a figura do conselho metropolitano e sua composição, e também indicou os poderes do presidente do conselho metropolitano e do diretor da região metropolitana, enquanto determinava o escopo dos conselhos metropolitanos. A lei estabeleceu que a direção e a administração da regiáo metropolitana ficariam a cargo do conselho metropolitano, do presidente do conselho metropolitano e do diretor apoiado pelas unidades técnicas indispensáveis para o desempenho de suas funções.

Os principais poderes do conselho metropolitano estão relacionados a sua capacidade de planejar o desenvolvimento harmônico, abrangente e sustentável do território, nos seguintes termos:

- declarar os atos metropolitanos de acordo com as disposiçóes da lei;

- adotar o PIDM com uma perspectiva de longo prazo que inclua o componente do planejamento físico territorial, de acordo com as disposiçôes legais vigentes; 
- harmonizar o PIDM com o Pemot;

- aprovar a coordenaçáo dos aspectos relacionados aos fatos metropolitanos e ao PIDM;

- declarar de utilidade pública ou interesse social os bens necessários para atender às necessidades previstas no PIDM;

- decretar a cobrança da participação em mais-valias de obras públicas ou a contribuição de avaliaçẫo, nos termos da lei;

- adotar políticas de mobilidade metropolitana e instrumentos de planejamento na área de transporte metropolitano a que as respectivas áreas devem estar sujeitas;

- definir as tarifas do serviço de transporte público de acordo com a concorrência; e

- formular recomendaçóes sobre política fiscal e financeira aos municípios que fazem parte da área, buscando especialmente a unificaçáo ou a harmonização integral dos sistemas tributários locais.

Finalmente, os conselhos metropolitanos atuam como assessores para a preparaçáo, a elaboração e a avaliação dos planos da entidade e recomendam os ajustes que devem ser introduzidos. Cada área metropolitana terá um conselho metropolitano de planejamento, e, além disso, poderão ser formados conselhos de mobilidade e transporte, de serviços públicos, de meio ambiente e outros considerados necessários, de acordo com os fatos metropolitanos definidos e as funçóes atribuídas por lei ou delegadas de acordo com elas.

A elaboração e a subsequente adoção do PIDM, que inclui o componente do planejamento físico territorial e sua harmonização com o Plano Estratégico Metropolitano de Planejamento Territorial, são percebidas como as duas atividades estratégicas mais importantes do arcabouço institucional metropolitano. Ambos os planos resumem a aplicaçáo dos instrumentos de planejamento e gestão territorial, bem como as indicaçóes para harmonizar os planos com as disposiçóes da norma nacional de planejamento urbano.

A Lei n $\mathrm{n}^{\mathrm{0}} 1.625$ definiu que os atos do conselho metropolitano serão chamados de acordos metropolitanos, nos quais os assuntos que pela Constituição e pela lei serão atribuídos à região metropolitana constituem uma hierarquia mais alta em relação aos atos administrativos municipais dentro de sua jurisdição.

Algo de extrema importância para a tomada de decisóes se relaciona ao fato de que os acordos metropolitanos possam ter origem nos membros do conselho metropolitano, no representante legal da região metropolitana, nos conselheiros 
dos municípios que o compóem e na iniciativa popular, de acordo com o art. 155 da Constituição Política, ${ }^{6}$ em relação à lista eleitoral.

Em termos de fontes de financiamento para as áreas metropolitanas, a Lei no 1.625 (art. 28), de 2013, indicou que os aluguéis serão compostos por:

- produto da sobretaxa de 2 por 1 mil na avaliação cadastral dos imóveis localizados na jurisdiçáo da respectiva região metropolitana, de acordo com o art. 317 da Constituição Política; ${ }^{7}$

- porcentagem das contribuiçóes de participação destinadas ao financiamento das funçóes das áreas metropolitanas estabelecidas pelos acordos municipais, nos termos do art. 25 da Lei no 1.454 , de $2011 ;^{8}$

- contribuiçóes, taxas, direitos, tarifas e multas por uso e exploração de recursos naturais renováveis;

- valores arrecadados por meio da contribuição de avaliaçáo para a execução de obras de natureza metropolitana;

- recursos provenientes de taxas, tarifas, direitos, multas ou autorizaçóes que receber no exercício da autoridade de transporte ou de outras autoridades que tenham sido concedidas ou reconhecidas; e

- itens de orçamento destinados à região metropolitana nos orçamentos nacionais, departamentais, distritais, municipais ou das entidades descentralizadas da ordem nacional, departamental, distrital ou municipal.

Como pode ser visto, existem várias fontes de financiamento para o desenvolvimento das atividades atribuídas às áreas metropolitanas, sendo as mais importantes: i) a sobretaxa de 2 por 1 mil na avaliação cadastral das propriedades localizadas na jurisdiçáo da respectiva área metropolitana; e ii) o

6. "Um número de cidadãos igual ou superior a $5 \%$ do censo eleitoral existente na respectiva data ou a $15 \%$ dos conselheiros ou deputados do país pode apresentar projetos de lei" (Colombia, 1991, art. 155, tradução nossa).

7. "Somente os municípios podem tributar imóveis. 0 exposto (...) não impede que outras entidades imponham uma contribuição de avaliação. A lei alocará um percentual desses impostos, que não poderá exceder a média das sobretaxas existentes, as entidades encarregadas de administrar e conservar o meio ambiente e os recursos naturais renováveis, de acordo com os planos de desenvolvimento dos municípios na área de sua jurisdição" (Colombia, 1991, art. 317, tradução nossa).

8. "Regime tributário especial para as áreas metropolitanas. No desenvolvimento do disposto no art. 319 da Constituição Política, além dos recursos que compõem o patrimônio e a renda das áreas metropolitanas, o projeto de constituição regulado pelo art. 5 da Lei no 128, de 1994, deve especificar as fontes das contribuiç̧ões das entidades territoriais que dela farão parte, bem como os percentuais de tais contribuições, de acordo com o disposto no art. 22 da Lei no 128, de 1994. Nas áreas metropolitanas constituídas até a presente data, cada conselho municipal, por iniciativa de seu prefeito, emitirá um acordo indicando as fontes das contribuiç̧ões com as quais o respectivo município se compromete para financiar as funções da entidade, como as porcentagens da referida participação. 0 ato administrativo que constitui uma área metropolitana será considerado uma regra geral obrigatória a qual cada conselho municipal obedecerá ao aprovar o orçamento anual da respectiva entidade membro" (Colombia, 2011a, art. 25, tradução nossa). 
percentual das contribuiçóes de participação destinadas ao financiamento das funçóes das áreas metropolitanas estabelecidas pelos acordos municipais (art. 25 da Lei no 1.454, de 2011).

O financiamento da área metropolitana tem maior segurança quando se exercem as funçóes e os poderes da autoridade ambiental no perímetro urbano (Lei no 99, de 1993, ${ }^{9}$ e art. 7o da Lei no 1.625, de 2013). Nesse caso, a área metropolitana obterá recursos da sobretaxa ambiental. Além disso, exerce-se a função de autoridade de transporte público na área de sua jurisdição, e a área metropolitana poderá receber recursos adicionais (art. 7음 da Lei $\mathrm{n}^{\circ}$ 1.625, de 2013). O requisito de acesso às funçóes da autoridade ambiental urbana estabelece que a área metropolitana deve ter uma população superior a 1 milhão de habitantes. Se isso for cumprido na área metropolitana, ela exercerá as mesmas funçóes atribuídas às corporaçôes autônomas regionais no perímetro urbano.

Uma das características básicas do sistema de financiamento da área metropolitana é que o governo central não é obrigado a alocar recursos para apoiar a execução de projetos metropolitanos, mas também náo é proibido financiar projetos baseados em fatos metropolitanos. Em geral, o governo nacional ordena recursos na forma de financiamento às entidades territoriais por meio do Sistema Geral de Participação. Por meio de diferentes ministérios e entidades descentralizadas, é possível fazer investimentos no território, dentro do qual o governo poderia propor projetos de investimento de natureza metropolitana.

A Constituição Política de 1991 estabeleceu as regras de distribuição da renda atual da nação que deveria ser transferida para as entidades territoriais. Considerou-se a necessidade de regulamentar os critérios de distribuição do Sistema Geral de Participação dos departamentos, distritos e municípios, bem como as disposiçóes necessárias para a operacionalizaçáo desse sistema, incorporando princípios objetivos a sua distribuição.

Conforme exposto, não existe um fundo nacional de desenvolvimento metropolitano. No entanto, o atual regulamento sobre as áreas metropolitanas (Lei no 1.625 , de 2013) estabeleceu os mecanismos pelos quais elas podem ativar diferentes formas de financiamento sem necessidade de recorrer a fundos nacionais.

O governo nacional pode alocar recursos do orçamento nacional como contrapartida aos recursos da área metropolitana em setores como educação (escolas), água potável (aquedutos) ou transporte (sistema de transporte de massa), desde que seja mostrada a viabilidade pública dos projetos.

9. É feita referência aos requisitos contidos no art. 66 da Lei no 99, de 1993, que estabelece a competência dos grandes centros urbanos: "Municípios, distritos ou áreas metropolitanas cuja população urbana seja igual ou superior a 1 milhão de habitantes (1.000.000) exercerão dentro do perímetro urbano as mesmas funções atribuídas às empresas autônomas regionais, aplicáveis ao ambiente urbano (...)" (Colombia, 1993, tradução nossa). 
Outra forma de financiamento para as atividades das áreas metropolitanas é aquela estabelecida a partir da inserção da iniciativa privada em obras de interesse público (infraestrutura urbana, prestaçáo de serviços públicos e empreendimentos). A trajetória histórica da participação privada começa com a Constituição Política de 1991, uma vez que, até o início da década de 1990, a prestação de serviços públicos estava a cargo do Estado, geralmente por meio de monopólios públicos nacionais ou municipais, criados para garantir o bem-estar da sociedade.

A Constituição Política de 1991 promoveu reformas econômicas e institucionais de livre mercado, a fim de passar de um Estado comercial para um Estado que regula as açóes de investidores privados, um Estado que promove a concorrência e controla a formação de monopólios. Somente em 2009, no entanto, o governo, a partir do documento do Conselho Nacional de Política Econômica e Social (Conpes), define a Associação Público-Privada (APP).

É uma tipologia geral de relacionamento público-privado incorporada em um contrato entre uma organizaçáo pública e uma empresa privada para a provisáo de bens públicos e serviços relacionados em um contexto de longo prazo, parcial ou totalmente financiado com pagamentos por resultados adiados ao longo do tempo pelo Estado (Conpes, 2009, p. 13, tradução nossa).

O Plano Nacional de Desenvolvimento (PND) (Lei no 1.450, de 2011) reconheceu a importância do setor privado para cumprir os objetivos estabelecidos. No capítulo Competitividade e crescimento da produtividade do PND, conclui-se que "na Colômbia, ainda é escassa a participação do setor privado no financiamento e desenvolvimento de infraestrutura econômica e social pública” (Colombia, 2011b, p. 11, tradução nossa).

Para cumprir os objetivos do PND 2010-2014 e aumentar a participação do setor privado em investimentos em infraestrutura, produtivos e sociais, foi promulgada a Lei no 1.508, de 2012: a Lei das Associaçóes Público-Privadas. É uma estrutura regulatória que incentiva os investidores privados a projetar, construir, operar e manter uma infraestrutura que ofereça serviços públicos de qualidade à população, cuja iniciativa pode ser do setor público ou privado.

A lei colombiana de APP inclui uma novidade, que é permitir que grupos privados apresentem iniciativas de APP ao Estado para o desenvolvimento de infraestrutura pública. Essas iniciativas devem ser analisadas pela entidade pública do Estado responsável pelas funçóes relacionadas à referida infraestrutura, e definir se a proposta deve ou não ser aceita, a qual deve ser formulada em termos técnicos, legais e financeiros pelo setor privado. 


\section{CONSIDERAÇÕES FINAIS}

Revisado o antecedente normativo relacionado à criação de uma área metropolitana na Colômbia, constatou-se que foi em 1968 (Ato Legislativo no 1 ) que a existência de áreas metropolitanas foi declarada pela primeira vez resultado da organização de dois ou mais municípios com o objetivo principal de melhorar a administração ou a prestação de serviços públicos.

A declaração da área metropolitana de 1968 teve que esperar onze anos para que a Lei no 3.104, de 1979, estabelecesse um regulamento completo para essas áreas ao ditar as regras para sua organização e operação, bem como as disposiçóes sobre financiamento. Em particular, os requisitos foram estabelecidos para que dois ou mais municípios do mesmo departamento pudessem ser constituídos em uma área metropolitana. Da mesma forma, foram formuladas as funções de planejamento e provisão de serviços públicos, aquelas relacionadas à contribuição de valorização e coordenação política administrativa e fiscal.

A Lei no 3.104 autorizou a constituição de áreas metropolitanas cujo núcleo principal eram os municípios de Medellín, Cali, Barranquilla, Bucaramanga e Pereira, desde que estas condiçóes fossem atendidas: o conceito positivo do DNP e a exigência de que o conjunto de municípios deveria ter uma população de, pelo menos, 300 mil habitantes e que a população do município principal náo poderia ser inferior a 250 mil habitantes. Como resultado, no início dos anos 1980, foram criadas as áreas metropolitanas do Vale do Aburrá (AMVAs) (Medellín), do Centro Ocidente (Pereira), de Barranquilla e de Bucaramanga.

Com a emissão do Código do Regime Municipal contido no Decreto-Lei no 1.333, de 1986, foram ratificadas as disposiçóes do Decreto no 3.104, de 1979, e, pela primeira vez, foram propostos os meios de sustentabilidade financeira, criando uma sobretaxa de 1 por 1 mil $(0,1 \%)$ na avaliação cadastral dos imóveis localizados na jurisdição de cada área.

Posteriormente, em 1994, foi emitida a Lei no 128 (Lei Orgânica das Áreas Metropolitanas), mantendo o objeto, a jurisdição e a natureza jurídica das áreas metropolitanas, mas introduzindo novos requisitos para sua constituição: um terço dos vereadores dos referidos municípios ou $5 \%$ dos cidadãos que compóem a lista eleitoral total dos mesmos municípios teriam iniciativa para promover sua criação, bem como os prefeitos dos municípios interessados.

Por fim, nessa cadeia de atos normativos, em 2013, foi emitida a Lei no 1.625 , regime para áreas metropolitanas, revogando a Lei Orgânica nº 128, de 1994. Essa lei é a que atualmente regula a criação de áreas metropolitanas e estabelece a validade do objeto, da natureza, dos poderes e das funçôes dessas áreas. Ela define as principais condições para a constituição das áreas metropolitanas, introduzindo a 
consulta popular que tornará a proposta para essa constituição favorável quando a maioria dos votos de cada um dos municípios interessados for favorável e a participação cidadã atingir pelo menos um quarto da população registrada no respectivo cadastro eleitoral de cada um dos municípios participantes.

A Lei no 1.625 introduz elementos muito importantes relacionados à capacidade da área metropolitana de influenciar tanto o desenvolvimento dos municípios que a compóem como o planejamento do território. Ela incorpora o conceito de fatos metropolitanos com impacto nos POTs, planos de desenvolvimento e outros instrumentos de planejamento. Da mesma forma, institui o que serão doravante os órgãos de governo e a administração das áreas metropolitanas, bem como as novas fontes de financiamento para as áreas metropolitanas.

É evidente que após a Lei no 1.625 , de 2013, nenhuma área metropolitana foi criada, porque acredita-se que essa regra dificulta a constituição de uma área metropolitana, já que o limiar estabelecido exige que a participação cidadã na consulta deve atingir pelo menos um quarto da populaçáo registrada no respectivo censo eleitoral de cada um dos municípios participantes.

Relacionado ao exposto, argumentos desfavoráveis são apresentados à constituição das áreas metropolitanas, como os altos custos associados à organização de uma consulta popular, bem como os riscos políticos inerentes ao processo. Com efeito, alcançar a participaçáo cidadã de pelo menos um quarto da população registrada no respectivo cadastro eleitoral de cada um dos municípios participantes implicaria o desenvolvimento de atividades para promover a iniciativa, que inevitavelmente incorreria em altos custos não disponíveis nos orçamentos municipais. Na sua ausência, provavelmente não garantiria a participaçáo de um quarto da população registrada no boletim eleitoral.

Conclui-se, portanto, que a condição imposta pela Lei $\mathrm{n}^{\mathrm{o}}$ 1.625, de 2013, desencoraja a criação de áreas metropolitanas. Isso é evidente na dificuldade enfrentada por iniciativas em cidades como Cali, Cartagena, Tunja, Armênia, Bogotá e Villavicencio, entre as mais importantes.

Portanto, na Colômbia, atualmente estão sendo discutidas iniciativas para modificar o percentual de participação na conformação de áreas metropolitanas, uma vez que se pensa que o legislador estabeleceu limites mais altos do que o que um prefeito normalmente alcança para ser eleito. A ideia é que, mantendo a figura da consulta popular, a porcentagem de participação cidadá possa ser reduzida, em um ambiente em que a abstenção é alta e em que os prefeitos são às vezes eleitos com números inferiores à porcentagem dos 25\% necessários para a constituição de áreas metropolitanas (DNP, 2017). 
Também se propóe que, em vez da condição de realizar uma consulta popular como requisito para formar áreas metropolitanas, seja determinado um procedimento de aprovação pelos conselhos municipais - sem deslegitimar os já estabelecidos para a participaçáo adequada das autoridades municipais da regiáo metropolitana nos órgãos administrativos -, bem como as regras de operação e financiamento de comum acordo com o disposto na Lei no 1.625 , de 2013. De fato, essa proposta implica reordenação do atual regulamento (DNP, 2017, p. 11).

Nesse sentido, a discussão atual na Colômbia gira em torno da necessidade de facilitar a constituição de áreas metropolitanas com critérios mais técnicos do que políticos, uma vez que os primeiros dão clareza à necessidade de gerenciar efetivamente as relaçôes funcionais entre municípios.

\section{GOVERNANÇA METROPOLITANA NA AMÉRICA LATINA: COLÔMBIA - ESTUDO DE CASO DA AMVA}

Esta seção apresenta o estudo de caso da Colômbia: a AMVA. Na primeira parte, é descrita a maneira pela qual a AMVA pôde cumprir as disposiçóes da norma nacional (Lei no 1.625, de 2013), formando sua própria estrutura orgânica para responder ao objetivo de planejamento do território metropolitano, bem como cumprir as funçóes atribuídas pela norma nacional.

Em particular, será relatada a maneira como a AMVA se adaptou às suas funçóes de planejamento, avançando na formulaçáo dos principais planos de desenvolvimento metropolitano e constituindo uma estrutura organizacional muito importante. Tal estrutura denota avanços significativos na governança sobre os mecanismos de produção de informaçôes e na elaboração de diretrizes metropolitanas com amplo impacto entre os municípios associados.

A seção termina com uma segunda parte, na qual são discutidas algumas ideias sobre o que pode ser o ensino dessa área metropolitana para o restante das formaçóes metropolitanas da Colômbia, bem como para a experiência das áreas metropolitanas da América Latina. Destaca-se a importância de formalizar novos mecanismos de relacionamento com os diferentes atores principais nos dez municípios que compõem a AMVA.

\subsection{Constituição e tamanho da AMVA}

A AMVA é uma entidade administrativa de direito público, com personalidade jurídica, autonomia administrativa, patrimônio próprio e regime administrativo e fiscal especial, autorizado pela Lei ํㅡㄴ 3.104, de 1979, e portarias departamentais nos 34, de 1980, e 61, de 1983. 
A AMVA foi criada com o compromisso de consolidar o progresso e o desenvolvimento harmonioso da região metropolitana, com funçốes de planejamento estratégico - ordenamento territorial, autoridade ambiental, autoridade de mobilidade e transporte público - e de coordenação - na prestação de serviços públicos, no sistema habitacional de interesse social, na execução de obras de infraestrutura viária e na formulação de projetos de interesse metropolitano.

A regiâo metropolitana do Vale do Aburrá reúne dez municípios da sub-região do Vale do Aburrá do departamento de Antioquia. Esses municípios estão ligados entre si por dinâmicas e inter-relaçóes territoriais, ambientais, econômicas, sociais, demográficas, culturais e tecnológicas.

\section{MAPA 1}

\section{Municípios da região metropolitana do Vale do Aburrá}

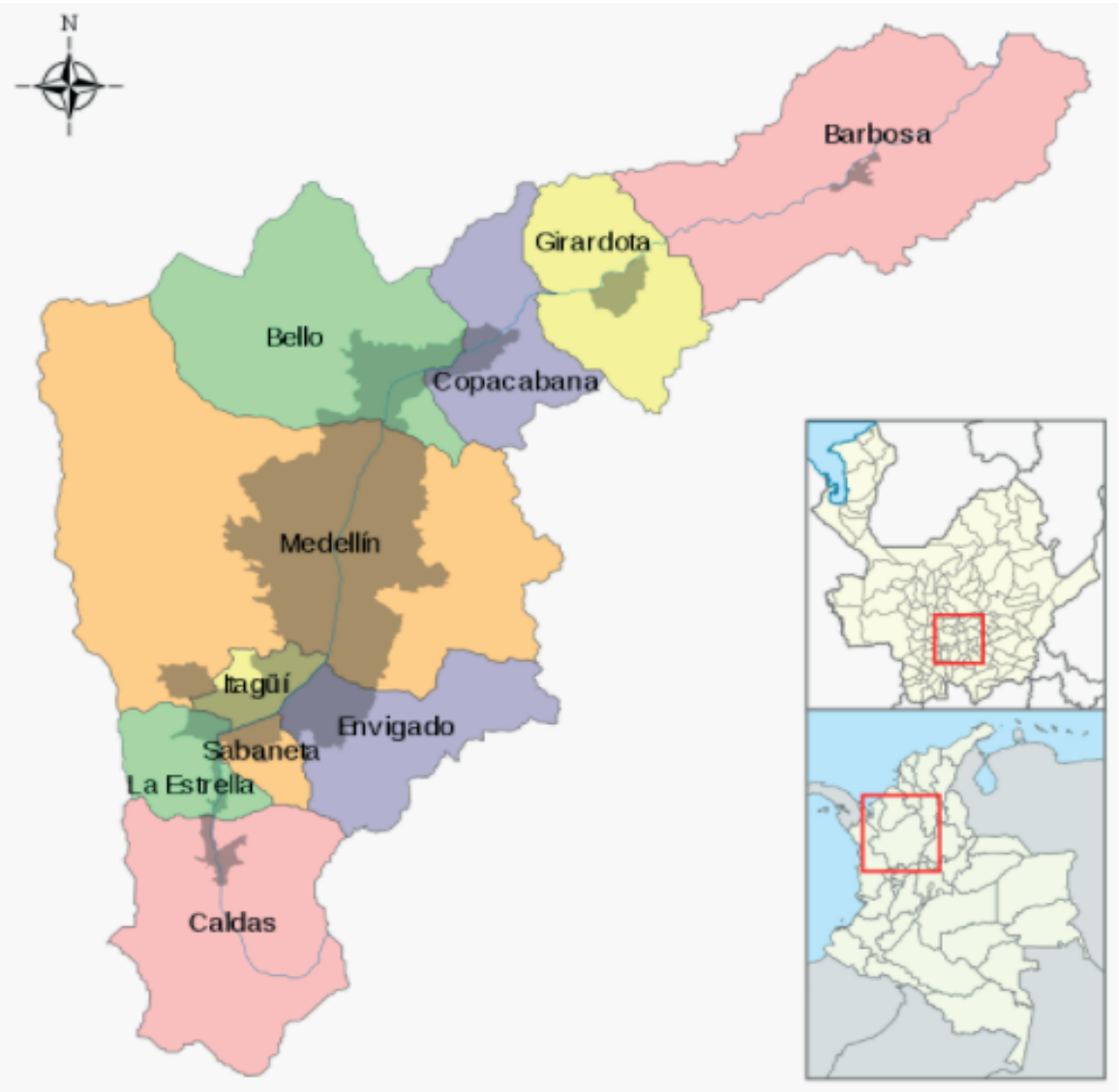

Fonte: AMVA.

Obs.: Figura reproduzida em baixa resolução e cujos leiaute e textos não puderam ser padronizados e revisados em virtude das condições técnicas dos originais (nota do Editorial). 
Sua cidade principal é Medellín (capital do departamento, com 2,4 milhóes de habitantes), e os outros membros são (do sul para o norte): Caldas, La Estrella, Sabaneta, Itagüí, Envigado, Bello, Copacabana, Girardota e Barbosa.

A região metropolitana está localizada no Vale do Aburrá, a uma altitude média de $1.538 \mathrm{~m}$, e sua populaçáo total chegava a 3,4 milhóes de habitantes em 2018, de acordo com o censo nacional de populaçáo realizado pelo Departamento Administrativo Nacional de Estatística (Dane), que constitui a área mais povoada da Colômbia. A AMVA contribui com aproximadamente $10 \%$ do produto interno bruto (PIB) do país.

\subsection{Estrutura e governança da AMVA}

Como será visto nas próximas subseçóes, a AMVA atende às características das áreas metropolitanas definidas na Lei no 1.625 , de 2013. A estrutura institucional e os instrumentos para o planejamento do território foram progressivamente formados e adotados pela AMVA nos quase quarenta anos de existência. A história de constituição da AMVA mostra como o consenso político permanente sobre a viabilidade da integração física, econômica, urbana e social dos municípios associados aumenta a capacidade de influenciar o planejamento territorial.

Desde a sua existência, a AMVA definiu sua própria estrutura regulatória para gerenciar a administração de suas funçóes. Uma figura de natureza normativa e indicativa denominada acordos metropolitanos contribuiu para isso e contém as decisóes que a AMVA toma em matéria de administração e execução das funçóes atribuídas como área metropolitana, consagradas na principal função do conselho metropolitano.

Os acordos metropolitanos concedem institucionalidade à AMVA e estabelecem as várias decisões regulatórias em todos os assuntos sujeitos a planejamento e que regulam a gestão do território metropolitano.

A partir dos acordos metropolitanos, são gerenciados os aspectos ambientais e de transporte mais importantes, como também são determinados os orçamentos anuais de receitas e despesas. Também é estabelecido o Plano Operacional Anual de Investimento, em que são adotadas as diretrizes e as determinaçóes sobre a gestáo do espaço público urbano verde, as taxas para o SITVA e o Plano Abrangente de Gerenciamento de Resíduos Sólidos, e são tomadas as decisóes administrativas mais importantes.

Por exemplo, o ato administrativo mais relevante para o exercício da gestão da administração metropolitana é o Acordo Metropolitano no 10 , de 2013, ${ }^{10}$ pelo qual os estatutos da AMVA são atualizados, modificados e adotados. 
Esse acordo metropolitano é de extrema importância, pois define os aspectos centrais da governança da AMVA, associados aos poderes e às funçóes que lhe são atribuídos, tais como:

- programar, planejar e coordenar o desenvolvimento harmonioso, integrado e sustentável da região dos municípios que que integram a área;

- racionalizar a prestação de serviços públicos pelos municípios que compóem a área;

- realizar obras de infraestrutura viária e desenvolver projetos de interesse social na região metropolitana do Vale do Aburrá; e

- estabelecer diretrizes e orientações específicas para a ordenação territorial dos municípios da jurisdição, a fim de promover e facilitar a harmonização de seus planos de planejamento territorial.

Segundo a Lei $\mathrm{n}^{-} 1.625$ (art. $7^{\circ}$ ), esse acordo metropolitano determina as funçóes da AMVA, entre as quais as mais relevantes são as seguintes:

- regular os fatos metropolitanos, de acordo com o disposto na lei;

- formular e adotar o PIDM com uma perspectiva de longo prazo, incluindo o componente do planejamento físico territorial;

- formular e adotar o PIDM, em consonância com os planos nacionais de desenvolvimento e os das entidades territoriais;

- formular e adotar o Pemot, que será a estrutura a que os municípios da AMVA devem aderir, ao adotar planos de uso do solo;

- executar obras de natureza metropolitana, de acordo com as disposiçóes do Pemot;

- exercer as funções e os poderes da autoridade ambiental no perímetro urbano, de acordo com o disposto na Lei no 99, de 1993;

- formular a política de mobilidade regional, no âmbito do Pemot, e exercer a função de autoridade de transporte público na área de sua jurisdição;

- formular e adotar instrumentos para o planejamento e desenvolvimento do transporte metropolitano, no âmbito do Pemot; e

- promover programas e projetos de natureza social no âmbito da gestão pública metropolitana, em questôes de saúde, educação, cultura, saneamento ambiental básico, recreação e esporte, estrutura produtiva, criação de emprego e políticas populacionais relevantes para o nível supramunicipal. 
O Acordo Metropolitano no 10, de 2013, que adota os estatutos da AMVA, também estabelece a estrutura e as funções dos órgãos de direção e administração, e determina que a autoridade máxima da AMVA é o conselho metropolitano, presidido pelo prefeito de Medellín (cidade central).

Por fim, a região metropolitana do Vale do Aburrá terá instâncias assessoras para a recomendação de ajustes, elaboração, avaliação de planos e programas da entidade, denominados conselhos metropolitanos. Além disso, existirão pelo menos os seguintes conselhos metropolitanos: o de planejamento, o de transporte público, o de habitação e o ambiental metropolitano. Na conformação dos conselhos metropolitanos, nota-se uma maior diversificação da participação da sociedade civil e de organizaçôes de caráter público e misto.

Após analisar a estrutura dos órgãos de direção e administração da AMVA, conclui-se que não há menção específica nos estatutos respectivos que organizam o conselho metropolitano que promova a participaçáo social e empresarial da sociedade civil ou de movimentos sociais. Assim, deve-se interpretar que o conselho metropolitano e seus órgáos de governo e administração são os únicos mecanismos com poderes para gerenciar o escopo e as funçôes da AMVA.

Um elemento crucial nesse contexto é o nível de autonomia da AMVA, uma vez que as questóes atribuídas à região metropolitana do Vale do Aburrá não estão sujeitas às disposiçóes da Assembleia Departamental nem do governo de Antioquia. Além disso, em nenhum caso os atos expedidos pela regiáo metropolitana do Vale do Aburrá, dado seu status de instância de planejamento e gestáo, podem violar a autonomia dos municípios que o compóem.

De acordo com os resultados de um estudo do DNP (2017), há uma sinergia muito positiva entre os conselhos setoriais metropolitanos, o conselho metropolitano e a maneira como os projetos a serem aprovados são discutidos primeiramente nos conselhos e, posteriormente, pelo conselho maior. Existem duas maneiras de discutir e formular projetos: do município para a área (microprojetos) e da área para o município (macroprojetos).

Quando são macroprojetos, a região metropolitana os prepara, mas busca-se que os resultados desses projetos impactem positivamente vários municípios. Quando são microprojetos, após o estabelecimento de diretrizes pela região metropolitana, os municípios formulam os projetos e orçamentos e os enviam para a regiáo metropolitana.

Durante o processo de formulação, a área coloca sua equipe técnica a serviço e, assim, os técnicos (da área e do município) se reúnem para definir os orçamentos e as especificaçóes do projeto. Quanto aos recursos para microprojetos, em alguns casos é uma combinação de recursos locais e metropolitanos e, em 
outros casos, é a área metropolitana que gerencia os recursos. Todos os projetos estão vinculados aos planos de desenvolvimento municipal e da área ao plano abrangente de desenvolvimento metropolitano. Uma vez aprovado o projeto, existem dois supervisores no processo de execução, um da região metropolitana e outro do município.

Da mesma forma, os municípios destacam de maneira positiva o apoio técnico recebido pela AMVA, tanto na formulação quanto na execução dos projetos, e também os pareceres técnicos prestados sobre os processos de atualização dos POTs realizados em alguns municípios. É por esse motivo que os municípios pertencentes à AMVA consideram que a gestão realizada pela área metropolitana tem sido boa e geralmente percebem que pertencer a ela representou benefícios para cada um deles.

\subsection{Instrumentos de planejamento e gestão na AMVA}

De acordo com o definido na Lei $\mathrm{n}^{\mathrm{o}} 1.625$, de 2013, as áreas metropolitanas devem formular um plano de desenvolvimento metropolitano abrangente e um Pemot. O Contrato no 10, de 2013, determina as funçóes da AMVA, e as descritas a seguir, em termos de planejamento, além de identificar e regular fatos metropolitanos, estão entre elas.

1) Formular e adotar o PIDM com uma perspectiva de longo prazo, incluindo o componente do planejamento físico territorial, de acordo com as disposiçôes legais vigentes.

2) Formular e adotar o Pemot, que será a estrutura a que os municípios da AMVA devem aderir ao adotar planos de uso da terra (Alcaldía de Medellín, 2013).

Atualmente, a AMVA possui o PIDM, que é, por lei, o instrumento fundamental para operar esses esquemas associativos, pois estabelece a visão, a missão e as formas de operar para lidar com soluçóes para os problemas e as necessidades identificados no território.

Assim, estabelece-se que o planejamento estratégico na regiáo metropolitana é regido pelo que é declarado e acordado no PIDM, considerado nas diretrizes para a sub-regiáo e o território metropolitano. Também define claramente programas e projetos de caráter metropolitano e dirige o cumprimento das funçóes da AMVA como entidade de planejamento, autoridade ambiental urbana nos dez municípios associados e autoridade de transporte em massa e metropolitano.

É importante observar que o PIDM, em seus projetos estratégicos e na formulação de objetivos e estratégias, segue as instruçôes definidas no acordo sobre as diretrizes de planejamento territorial metropolitano (Acordo 
Metropolitano no 15, de 2006). Além disso, baseia-se em planos setoriais que têm relação direta com a organização territorial da região metropolitana do Vale do Aburrá: i) Plano de Gerenciamento de Resíduos Sólidos; ii) Plano Diretor de Espaços Verdes Urbanos da AMVA; iii) formulação do Plano Diretor de Mobilidade para a regiáo metropolitana; e iv) Plano de Gerenciamento e Organização da Bacia do Rio Aburrá, a estratégia de gerenciamento do Parque Central de Antioquia (PCA).

Por sua vez, o Pemot continua, em 2019, sua etapa de avanços no diagnóstico e na formulação. O Pemot foi definido como um exercício de planejamento territorial com uma abordagem sistêmica e a favor da sustentabilidade, que buscará harmonizar os planos de planejamento dos dez municípios com relação a questóes estratégicas.

Segundo as próprias autoridades municipais, o Pemot é um plano estratégico que traça a rota e o modelo de ocupação desses dez municípios para atingir territórios integrados e, assim, ter uma área metropolitana sustentável no futuro. O objetivo fundamental é alcançar a harmonização dos POTs dos dez municípios, levando em consideração a existência de relaçôes no nível territorial em questóes como estrutura natural, serviços públicos, sistemas de mobilidade e estruturas sociais e econômicas. O objetivo é definir um modelo de ocupação que permita a harmonização do território metropolitano e regional.

Até o momento da formulação, o Pemot teve a participação de setores competentes com as questôes de ordenamento territorial metropolitano: escritórios municipais, conselhos municipais, conselhos e coletivos ambientais, conselhos de planejamento territorial, mídia alternativa de comunicação, academia, governo de Antioquia, Asociación Nacional de Empresarios de Colombia (Andi), conselho metropolitano de planejamento, administração e equipe profissional da região metropolitana.

Em resumo, a estratégia visa implementar a articulação do planejamento e gerenciamento do desenvolvimento com base nos conteúdos e recomendaçóes contidos no PIDM, em um cenário de planejamento no qual as diretrizes do Pemot, embora estejam sendo elaboradas, incluem aspectos importantes para a sustentabilidade, como:

- definição da estratégia e do sistema de gestão abrangente da água;

- estabelecimento do sistema metropolitano de rodovias e transporte público urbano;

- determinação do sistema de equipamentos metropolitanos; 
- dimensionamento e definição da estratégia de habitação social e prioritária na região metropolitana e dos instrumentos de gestão fundiária destinados a esse fim; e

- ordenamento de terras rurais e suburbanas.

Por fim, nos referimos ao Plano de Gerenciamento 2016-2019: territórios integrados, considerado um documento estratégico de curto e médio prazo, que serve como uma diretriz para orientar e coordenar o planejamento e e o gerenciamento metropolitano. $\mathrm{O}$ foco de atençáo do plano de gestáo é a consolidação de territórios integrados no Vale do Aburrá, que deve estar em sintonia com a visão prospectiva definida no Plano Integral de Desenvolvimento Metropolitano 2008-2020: rumo à integração regional sustentável. Assim, o principal objetivo do Plano de Gestão 2016-2019 é "alcançar um alto nível de coordenação e acordo para o desenvolvimento sustentável, a equidade humana e territorial, a convivência e a paz no território metropolitano" (Área Metropolitana del Valle de Aburrá, 2016, tradução nossa).

Esse plano de manejo, em correspondência com as diferentes diretrizes estratégicas estabelecidas no PIDM, propõe a consolidação da integração territorial e a articulação de diferentes atores, instâncias, instrumentos, estratégias e esforços de planejamento formulados na região metropolitana.

O Plano de Gerenciamento de Territórios Integrados 2016-2019 está estruturado em seis linhas estratégicas e quatro eixos transversais ao planejamento territorial, conforme a seguir.

QUADRO 1

Seis linhas estratégicas

\begin{tabular}{|c|c|c|}
\hline $\begin{array}{c}\text { Linha 1: planejamento e gestão } \\
\text { para a equidade }\end{array}$ & $\begin{array}{c}\text { Linha 2: qualidade ambiental e } \\
\text { desenvolvimento sustentável }\end{array}$ & $\begin{array}{c}\text { Linha 3: mobilidade sustentável, segura } \\
\text { e amável }\end{array}$ \\
\hline Linha 4: seguridade, convivência e paz & $\begin{array}{c}\text { Linha 5: suporte institucional, gestão } \\
\text { e cooperação }\end{array}$ & $\begin{array}{c}\text { Linha 6: comunicação pública e } \\
\text { mobilidade social }\end{array}$ \\
\hline
\end{tabular}

Elaboração dos autores.

QUADRO 2

Quatro eixos transversais

\begin{tabular}{|l|l|l|l|}
\hline $\begin{array}{l}\text { Alienação com o planejamento } \\
\text { nacional e departamental }\end{array}$ & Diretrizes metropolitanas & $\begin{array}{l}\text { Articulação integral com o } \\
\text { planejamento dos territórios } \\
\text { com o Vale do Aburrá }\end{array}$ & $\begin{array}{l}\text { Compromissos éticos universais } \\
\text { (Objetivos de Desenvolvimento } \\
\text { Sustentável - ODS) }\end{array}$ \\
\hline
\end{tabular}

Elaboração dos autores.

As FPICs são mais bem identificadas no Plano de Gerenciamento de Territórios Integrados 2016-2019. O plano parte da consideração de que existem 
problemas ambientais locais e regionais comuns - poluição do ar, água, mudanças climáticas e adaptação a ele -, e nos quais a AMVA encontra uma linha estratégica para seu desempenho.

Além disso, os municípios associados precisam repensar, estruturar e integrar sistemas de mobilidade com uma perspectiva ambiental, uma vez que o setor de transportes representa uma das áreas com maior impacto na melhoria da qualidade ambiental (em especial do ar), bem como na economia e no acesso aos territórios integrados. Portanto, propóe-se a implementação de sistemas de mobilidade ativos e sustentáveis, apoiados na rede de meios que compóem o Sistema Integrado de Transporte del Valle de Aburrá (SITVA): o metrô, o metrocable, o bonde, entre outros, que fazem parte de um sistema que nutre e complementa o transporte em todo o país e do Vale do Aburrá.

O Plano de Gerenciamento de Territórios Integrados 2016-2019, baseado nas seis linhas estratégicas, é encarregado de gerenciar o consentimento livre, prévio e informado (CLPI), estabelecendo os objetivos e programas associados a cada linha, conforme mostrado a seguir.

1) Planejamento e gestão da equidade: promover a equidade humana e territorial, a melhoria do habitat afetivo e efetivo, e articulação, programação e coordenação adequadas do desenvolvimento harmonioso, integrado e sustentável do território metropolitano.

2) Qualidade ambiental e desenvolvimento sustentável: fortalecer a função de autoridade ambiental da entidade, com base na articulaçáo interinstitucional sobre gestão da qualidade ambiental, para garantir a sustentabilidade no uso e na exploração dos recursos naturais pela sociedade metropolitana, ao mesmo tempo que é promovida uma cultura de apropriação e cuidado do território habitado, bem como o atendimento de demandas no Vale do Aburrá.

3) Mobilidade sustentável, segura e amigável: articular a gestão institucional para promover o diálogo e as açóes conjuntas concertadas, buscando consolidar uma mobilidade eficiente, equitativa, sustentável e segura a partir da integração de diferentes modos de transporte no Vale do Aburrá, além de promover uma cultura cidadã responsável diante de suas decisóes de mobilidade e viagens no território metropolitano.

4) Segurança, coexistência e paz: articular esforços institucionais, públicos e privados, com a vontade e a colaboração dos cidadáos metropolitanos, para aumentar a capacidade efetiva de resposta diante de informalidades, ilegalidades e violências recorrentes, a fim de promover uma aliança 
social inclusiva e participativa pela segurança, coexistência, reconciliação e construção da paz nos territórios integrados do Vale do Aburrá.

5) Apoio institucional, gestão e cooperação: gerar processos de articulação das açóes que contribuem para soluçóes de equidade social e territorial, apoiando os processos de desenvolvimento gerencial da região metropolitana e dos municípios por meio de processos de apoio e cooperação e alianças.

6) Comunicação pública e mobilização social: promover um processo de comunicação pública e mobilização social que favoreça o relacionamento e o diálogo permanente entre os diferentes atores envolvidos no desenvolvimento do Vale do Aburrá para a geração de acordos comuns de ação e transformação positiva de nossas condições de vida.

O Plano de Gerenciamento de Territórios Integrados 2016-2019 define seis linhas estratégicas nas quais o investimento é focado por meio de programas estratégicos, que orientarão o desenvolvimento e a implementação de projetos e açôes nos territórios integrados do Vale do Aburrá. As seis linhas implantadas em 36 programas destinaram uma quantia, em pesos, de 1,1 bilhão (US\$345.390.971) em recursos.

TABELA 1

Investimento por linhas estratégicas do Plano de Gerenciamento de Territórios Integrados 2016-2019

\begin{tabular}{lcc}
\hline Linhas estratégicas & Valor (pesos) & Valor (US\$) \\
\hline L1: planejamento e gestão para a equidade & 198.741 .207 .693 & 62.718 .525 \\
L2: qualidade ambiental e desenvolvimento sustentável & 233.378 .889 .356 & 73.649 .445 \\
L3: mobilidade sustentável, segura e amável & 543.795 .000 .000 & 171.610 .210 \\
L4: seguridade, convivência e paz & 39.750 .000 .000 & 12.544 .260 \\
L5: suporte institucional, gestão e cooperação & 53.952 .902 .951 & 17.026 .396 \\
L6: comunicação pública e mobilização social & 24.850 .000 .000 & 7.842 .135 \\
Total & $\mathbf{1 . 0 9 4 . 4 6 8 . 0 0 0 . 0 0 0}$ & $\mathbf{3 4 5 . 3 9 0 . 9 7 1}$ \\
\hline
\end{tabular}

Fonte: Área Metropolitana del Valle de Aburrá (2016).

Em resumo, o PIMD, juntamente com o Plano de Gerenciamento de Territórios Integrados 2016-2019, fornece os elementos básicos para o planejamento territorial dos municípios associados nos quais as FPICs são implementadas na AMVA.

\subsection{Apoio técnico e financeiro ao desenvolvimento na AMVA}

O Acordo Metropolitano no 10, de 2013, em seu capítulo Patrimônio e renda (art. 44), indica que a renda da AMVA será constituída por: 
- produto da sobretaxa de 2 por 1 mil na avaliação cadastral das propriedades localizadas na jurisdição da AMVA;

- percentual das contribuiçóes de participação destinadas ao financiamento das funçōes da região metropolitana do Vale do Aburrá, que devem estabelecer os acordos municipais (art. 25 da Lei no 1.454, de 2011);

- contribuiçóes, direitos, taxas e multas por uso e exploração de recursos naturais renováveis;

- valores arrecadados, que serão serão utilizados para a execução de obras de natureza metropolitana;

- recursos provenientes de taxas, tarifas, direitos, multas ou permissóes que receber no exercício das autoridades de transporte, meio ambiente ou outras autoridades que tenham sido concedidas ou reconhecidas;

- itens de orçamento destinados à AMVA no orçamento nacional, departamental, distrital, municipal ou descentralizado da ordem nacional, departamental, distrital ou municipal; e

- recursos provenientes da participação em ganhos de capital gerados pela execução de obras realizadas na região metropolitana do Vale do Aburrá, de acordo com o Plano Global de Desenvolvimento Metropolitano e de acordo com as leis em vigor (Alcaldía de Medellín, 2013).

Para garantir a contribuição dos municípios associados à área metropolitana, no art. 9 do mencionado acordo metropolitano - que regula as relaçôes entre a regiáo metropolitana do Vale do Aburrá e os municípios que o compóem -, fica estabelecido que ele corresponde a cada conselho municipal por iniciativa de seu prefeito para emitir um acordo no qual fontes e porcentagens são indicadas das contribuiçóes com as quais o respectivo município se compromete com o financiamento das funçóes da região metropolitana do Vale do Aburrá, em conformidade com o disposto nas leis $\mathrm{n}^{\mathrm{os}} 1.454$, de 2011, e 1.625, de 2013.

Como autoridade ambiental, a AMVA recebe os recursos: i) de sobretaxa ambiental; e ii) de autoridade ambiental urbana.

A análise do orçamento de renda e recursos da AMVA (Acordo Metropolitano no 17 , de 2017) indica que, do orçamento total de 334,804 milhóes de pesos, os recursos obtidos por ser uma autoridade ambiental representam $65,5 \%$ da receita total para o período de 2018 . 


\section{TABELA 2}

Orçamento de renda e recursos de capital da AMVA (2018)

\begin{tabular}{lccccc}
\hline Tipos de recurso & $\begin{array}{c}\text { Ingressos correntes } \\
(1 \text { mil pesos })\end{array}$ & $\begin{array}{c}\text { Ingressos de capital } \\
(1 \text { mil pesos) }\end{array}$ & $\begin{array}{c}\text { Total de } \\
\text { arrecadação (1 mil pesos) }\end{array}$ & US\$ & $\begin{array}{c}\text { Fontes } \\
(\%)\end{array}$ \\
\hline Recursos ambientais & 204.171 .800 & 14.978 .000 & $\mathbf{2 1 9 . 1 4 9 . 8 0 0}$ & 67.435 .895 & 65,5 \\
Recursos de livre destinação & 95.755 .200 & 5.055 .000 & $\mathbf{1 0 0 . 8 1 0 . 2 0 0}$ & 31.020 .909 & 30,1 \\
$\begin{array}{l}\text { Recursos de taxas retributivas } \\
\text { e taxas de uso }\end{array}$ & 7.164 .000 & 4.559 .000 & $\mathbf{1 1 . 7 2 3 . 0 0 0}$ & 3.607 .354 & 3,5 \\
$\begin{array}{l}\text { Cofinanciamento } \\
\begin{array}{l}\text { Total de apropriação } \\
\text { de recursos }\end{array}\end{array}$ & $\mathbf{3 0 7 . 0 9 1 . 0 0 0}$ & $\mathbf{2 7 . 7 1 3 . 0 0 0}$ & $\mathbf{3 3 4 . 8 0 4 . 0 0 0}$ & $\mathbf{1 0 3 . 1 2 4 . 5 4 0}$ & $\mathbf{1 0 0 , 0}$ \\
\hline
\end{tabular}

Fonte: Alcaldía de Medellín (2019).

Note-se que os recursos da AMVA são obtidos de fontes associadas à intervenção territorial descrita e que o governo nacional não aloca nenhum orçamento que possa aumentar a renda atual. Nesse sentido, pode-se afirmar que o governo nacional não transfere recursos que poderiam ser utilizados para financiar investimentos no nível territorial em que a AMVA atua.

Uma análise da evolução da renda das áreas metropolitanas constituídas na Colômbia indica que a AMVA aplica $71,2 \%$ da receita, seguida pela regiáo metropolitana de Bucaramanga, com 10,1\%, e pela regiáo metropolitana de Barranquilla, com 10,5\%. As razóes para o maior volume de renda da AMVA são explicadas com base em uma autoridade ambiental e na contribuição diligente dos municípios associados.

TABELA 3

Evolução da renda total das áreas metropolitanas (2010-2016)

(Em milhões de pesos constantes)

\begin{tabular}{lrrrrrrrrrr}
\hline Área metropolitana & 2010 & 2011 & 2012 & 2013 & 2014 & 2015 & 2016 & Total & $\begin{array}{c}\text { Total } \\
\text { (US\$ milhões) }\end{array}$ \\
\hline Vale do Aburrá & 277.596 & 252.400 & 236.949 & 339.062 & 432.260 & 433.098 & 357.091 & $\mathbf{2 . 3 2 8 . 4 5 6}$ & $\mathbf{7 7 6 , 2}$ & 71,2 \\
Bucaramanga & 20.809 & 15.939 & 24.808 & 62.212 & 58.808 & 82.783 & 65.747 & $\mathbf{3 3 1 . 1 0 6}$ & $\mathbf{1 1 0 , 4}$ & 10,1 \\
Barranquilla & 34.028 & 55.247 & 46.637 & 52.920 & 24.681 & 84.211 & 44.251 & $\mathbf{3 4 1 . 9 7 5}$ & $\mathbf{1 1 4 , 0}$ & 10,5 \\
Centro Ocidente & 32.604 & 31.985 & 29.492 & 28.004 & 28.745 & 30.685 & 31.705 & $\mathbf{2 1 3 . 2 2 0}$ & $\mathbf{7 1 , 1}$ & 6,5 \\
Cúcuta & 2.759 & 4.024 & 10.433 & 16.693 & 5.573 & 8.927 & 3.732 & $\mathbf{5 2 . 1 4 1}$ & $\mathbf{1 7 , 4}$ & 1,6 \\
Valledupar & 0 & 0 & 0 & 0 & 690 & 485 & 562 & $\mathbf{1 . 7 3 7}$ & $\mathbf{0 , 6}$ & 0,1 \\
Total & $\mathbf{3 6 7 . 7 9 6}$ & $\mathbf{3 5 9 . 5 9 5}$ & $\mathbf{3 4 8 . 3 1 8}$ & $\mathbf{4 9 8 . 8 9 0}$ & $\mathbf{5 5 0 . 7 5 6}$ & $\mathbf{6 4 0 . 1 8 9}$ & $\mathbf{5 0 3 . 0 8 9}$ & $\mathbf{3 . 2 6 8 . 6 3 3}$ & $\mathbf{1 . 0 9 0}$ & $\mathbf{1 0 0 , 0}$ \\
\hline
\end{tabular}

Fonte: DNP (2017).

Tampouco existe um fundo orçamentário estadual para apoiar as atividades da AMVA. Como pode ser visto na legislaçâo nacional (Lei no 3.526, de 2013), não há disposiçôes que digam que o Estado tenha compromissos orçamentários 
com as áreas metropolitanas estabelecidas na Colômbia e que não existe uma regra que force o Estado a formular instrumentos de financiamento para atividades realizadas por essas áreas.

Por fim, não está claro que existam iniciativas privadas que visem complementar o exercício de investimento nos próprios programas de desenvolvimento territorial da AMVA. O principal desafio do financiamento metropolitano está na necessidade de diversificar suas fontes de financiamento, diferentes das fontes convencionais, visto que estas limitam o grau de investimento em comparaçáo com a magnitude das propostas de uma ordem metropolitana. Por enquanto, não se sabe se a AMVA poderia promover opçóes como parcerias público-privadas que possivelmente trariam maiores oportunidades de investimento do setor privado, especialmente no campo da infraestrutura.

\section{CONCLUSÕES}

A Lei no 1.625 , de 2013, forneceu às áreas metropolitanas instrumentos para influenciar tanto o desenvolvimento dos municípios quanto o planejamento do território é feito. Permitiu, ainda, a incorporação do conceito de fatos metropolitanos com impacto nos planos de uso do solo, planos de desenvolvimento e outros instrumentos de planejamento. Da mesma forma, definiu os órgãos de direção e administração nas áreas metropolitanas, bem como suas novas fontes de financiamento.

É evidente que após a emissão da Lei no 1.625 , de 2013, não foram criadas novas áreas metropolitanas, em parte porque a referida norma dificulta a constituição de uma regiáo metropolitana. Deve-se atentar que o limiar estabelece que a participação cidadã da consulta deve atingir pelo menos um quarto da populaçáo registrada no respectivo registro eleitoral de cada um dos municípios participantes.

Como ilustrado, a estrutura institucional da AMVA está contida nos chamados acordos metropolitanos, que garantem as várias decisões que regulam a gestão do território metropolitano. E é por meio desses acordos que a AMVA gerencia os aspectos ambientais mais importantes, como transporte, orçamento anual de aluguéis e despesas, e estabelece as taxas do SITVA. Além disso, é adotado o Plano Abrangente de Gerenciamento de Resíduos Sólidos, e as decisóes administrativas mais importantes são tomadas.

Observou-se também como os planos estratégicos fornecem os elementos básicos para a ordenação territorial dos municípios associados nos quais as FPICs na AMVA são implementadas. Constatou-se que o conjunto de disposiçóes de natureza metropolitana se expressa em mecanismos que regulam a ordenação territorial, ao mesmo tempo que promovem circuitos de coordenação entre 
o conjunto de autoridades municipais que propóem objetivos e metas de desenvolvimento comuns aos municípios associados para a área metropolitana.

A existência de certos órgãos de decisão (conselho metropolitano, diretoria de área metropolitana e comitês consultivos) possibilita a coordenação de estratégias, programas e projetos de desenvolvimento metropolitano nas diferentes áreas do desenvolvimento econômico, social, cultural e ambiental do grupo de municípios que fazem parte da área metropolitana.

Os órgãos de decisão estabelecidos viabilizam a participação dos diferentes atores municipais e metropolitanos e asseguram a comunicação do andamento dos principais planos de desenvolvimento da ordem metropolitana.

Uma característica marcante da institucionalidade da AMVA é o baixo nível de relacionamento com o estado central da Colômbia. As instituiçóes da AMVA mostram que são capazes o suficiente de gerenciar o desenvolvimento do território, composto por dez municípios. Seu grau de autossuficiência financeira lhe dá independência para desenvolver as principais estratégias de desenvolvimento territorial.

A AMVA é, sem dúvida, a organização metropolitana mais avançada da Colômbia em termos do esquema associativo adaptado à Lei no 3.526 , de 2013 , com objetivos totalmente definidos para o gerenciamento do uso da terra e com uma estrutura administrativa funcional no interesse dos dez municípios associados.

Sua organização em diferentes níveis administrativos (conselho metropolitano, diretoria de área metropolitana, subdireçóes temáticas e administrativas e conselhos consultivos), no contexto de uma estrutura que regula as funções de cada órgão administrativo, faz da AMVA uma instituição focada em planejamento da ordenação territorial em uma extensa área na qual dez municípios se estabelecem.

É claro que existem mecanismos de coordenação que tornam a estrutura administrativa da AMVA funcional para os interesses e necessidades das administraçóes locais dos municípios associados. A representação dos municípios associados à AMVA em órgãos de administração, como o Conselho de Administração, significa que seus interesses estão totalmente representados no esquema associativo, e as decisóes sobre os aspectos mais importantes do desenvolvimento metropolitano são tomadas com base em sua representação.

Os principais instrumentos de planejamento descritos abrangem o diagnóstico dos dez municípios participantes e permitem que decisóes de investimento sejam associadas a impactos territoriais no conjunto de municípios associados. 
Pode-se afirmar que a governança metropolitana naAMVA estáedificada sobre mecanismos de planejamento e concertação que estabelecem a representação dos territórios, respeitando os sistemas de planificação municipal, contribuindo com assistência técnica e observando os diferentes sistemas de planificação existentes na função de escalas de integração dos municípios da área metropolitana.

Esses níveis de governança metropolitana dependem mais do sistema de representação local do que dos sistemas de representação nacional. Em outras palavras, a governança estabelecida na AMVA baseia-se mais nos níveis de representaçáo funcional dos municípios associados do que na formação de mecanismos de coordenação com os diferentes níveis da ordem nacional do Estado. É por isso que a AMVA é mais identificada com um desenvolvimento territorial do que com um desenvolvimento nacional.

Um dos principais desafios da governança metropolitana é expandir a margem de participação para os diferentes atores que se revelam decisivos na evolução dos aspectos econômicos, sociais e ambientais dos territórios associados. Uma maior participação do setor privado e de associaçóes da sociedade civil poderia promover novos arranjos institucionais e maior pluralidade na tomada de decisóes que vão além do estritamente considerado planejamento urbano e admitem a oportunidade de acrescentar visóes de desenvolvimento territorial da perspectiva do desenvolvimento local dos dez municípios associados.

Nessa ordem de ideias, para o caso colombiano, é aconselhável discutir se as decisões do conselho metropolitano são suficientes para melhorar a assembleia territorial entre os diferentes parceiros, embora seja necessário expandir a margem de participação para visôes de desenvolvimento territorial mais diversificado e inclusivo.

Por isso, é de extrema importância incorporar a visão de desenvolvimento da perspectiva do cidadão e em termos de suas aspiraçóes na provisão de direitos fundamentais, como o acesso à moradia em ambientes de sustentabilidade urbana. $\mathrm{O}$ esforço deve ser orientado para promover as maneiras pelas quais os objetivos da provisão de moradias estão institucionalmente ligados aos propósitos do desenvolvimento urbano e regional.

Os níveis desiguais de desenvolvimento que os diferentes municípios implicam indicam que é necessário fornecer informaçóes sobre as lacunas sociais, econômicas e territoriais, para iniciar açóes metropolitanas que proponham a redução da desigualdade, por exemplo, nos níveis de atenção à saúde, à provisão de infraestrutura educacional e à infraestrutura viária.

Em relação à governança fiscal e tributária, o município de Medellín poderia prestar assistência técnica para a modernização das informaçóes cadastrais 
nos diferentes municípios, como uma alternativa para fortalecer os sistemas tributários locais.

Cabe ao nível superior da administração metropolitana melhorar as capacidades técnicas e políticas dos municípios associados em relação ao planejamento da ordenação territorial. Assim, embora exista uma formulação para o desenvolvimento metropolitano, será necessário atender às necessidades de qualificação e treinamento técnico exigidas pelo trabalho de planejamento do território em cada município. Por exemplo, é necessário abordar a análise de risco associada aos planos de mitigação que permitem controlar o efeito negativo de eventos naturais.

A AMVA conseguiu formular um modelo regulatório que reforça suas capacidades de governança metropolitana, mas será necessário continuar sua construção nos outros territórios, incluindo vários atores sociais que até agora não foram levados em consideração. Em resumo, será necessário consolidar o modelo de governança, expandindo os processos de participação na tomada de decisão nas três instâncias da organização metropolitana: sociedade civil, governos locais e setor privado.

O maior desafio para o futuro é melhorar o modelo de governança metropolitana, ampliando o número de atores sociais e incentivando uma maior contribuição da ordem local na construção de uma visão abrangente do desenvolvimento territorial. Sempre será necessário ativar múltiplos espaços de diálogo, consulta, planejamento e coordenação, além dos mecanismos de gestão estabelecidos nos regulamentos nacionais e metropolitanos. Além disso, é preciso desenvolver iniciativas paralelas, processos, instrumentos e espaços de diálogo que promovam uma visão metropolitana mais inclusiva.

Todos os aspectos anteriores requerem uma agenda de pesquisa acadêmica que, a partir de uma análise completa das características físicas, sociais, ambientais e econômicas do território, proponha novas trajetórias de integração territorial. O objetivo principal é reduzir as diferenças entre os municípios associados, a fim de tornar a região metropolitana uma oportunidade para o desenvolvimento territorial mais ligada ao desenvolvimento territorial nacional e, é claro, com relaçóes mais permanentes com as mudanças no contexto latino-americano e mundial.

\section{REFERÊNCIAS}

ALCALDÍA DE MEDELLÍN. Acuerdo Metropolitano n⿳o 10 , de 2013. Por medio del cual se modifican y adoptan los estatutos del Área Metropolitana del Valle de Aburrá. Gaceta Oficial, n. 4174, jul. 2013. 
Acuerdo Metropolitano no 17, de 2017. Per el cual se establece el Presupuesto Anual de Rentas y Gastos y el Plan Operativo Anual de Inversiones para la vigencia fiscal 2018. Gaceta Oficial, n. 4635, 2019.

ÁREA METROPOLITANA DEL VALLE DE ABURRÁ. 2008-2020 Metrópoli: hacia la integración regional sostenible. Medellín: Área Metropolitana de Valle del Aburrá, 2007.

. Plan de Gestión 2016-2019: territorios integrados. Medellín: Área Metropolitana del Valle de Aburrá, 2016.

COLOMBIA. Acto Legislativo no 1 , de 1968. Por el cual se reforma la Constitución Política de Colombia. Diario Oficial, n. 32673, dic. 1968.

. Decreto no 3.104, de 1979. Por el cual se dictan normas para la organización y funcionamiento de las áreas metropolitanas. Diario Oficial, n. 35432, 1979.

. Constitución Política de Colombia 1991. Gaceta Constitucional, n. 116, 20 jul. 1991.

. Ley no 99, de 1993. Por la cual se crea el Ministerio del Medio Ambiente, se reordena el Sector Público encargado de la gestión y conservación del medio ambiente y los recursos naturales renovables, y se organiza el Sistema Nacional Ambiental, SINA, y se dictan otras disposiciones. Diario Oficial, n. 41146, 1993.

Ley no 1.454 , de 2011. Por la cual se dictan normas orgánicas sobre ordenamiento territorial y se modifican otras disposiciones. Diario Oficial, n. 48115, 2011a.

. Ley $\mathrm{n}^{\circ}$ 1.450, de 2011. Por la cual se expide el Plan Nacional de Desarrollo, 2010-2014. Diario Oficial, n. 48102, 2011 b.

. Ley no 1.625 , de 2013. Por la cual se expide el régimen actual de las áreas metropolitanas. Diario Oficial, n. 48776, 2013.

CONPES - CONSEJO NACIONAL DE POLÍTICA ECONÓMICA Y SOCIAL. Iniciativa para la modernización y gestión de activos fijos públicos. Bogotá: Conpes, 28 sept. 2009. p. 13.

DNP - DEPARTAMENTO NACIONAL DE PLANEACIÓN. Evaluación institucional y de resultados de las áreas metropolitanas y otros esquemas asociativos territoriales, con el fin de determinar los efectos de la asociatividad en términos de desarrollo económico y social. [s.l.]: DNP, 2017. 


\section{BIBLIOGRAFIA COMPLEMENTAR}

ALCALDÍA DE MEDELLÍN. Acuerdo Metropolitano nº 18, de 2001. En virtud del cual se adopta el "Proyecto Metrópoli 2002-2020: hacia una ecorregión, metropolitana educadora, gobernable, sostenible, competitiva, confiable e integrada social y globalmente", como instrumento de actualización y re formulación del Plan Integral de Desarrollo de 1985 "para la consolidación de la metrópoli”. Gaceta Oficial, n. 1612, 2001.

. Acuerdo Metropolitano no 15, de 2006. Por medio del cual se adoptan las normas obligatoriamente generales en materia de planeación y gestión del suelo y se dictan otras disposiciones. Gaceta Oficial, n. 2834, oct. 2006.

. Acuerdo Metropolitano no 40, de 2007. Gaceta Oficial, n. 3123, 2007.

. Acuerdo no 14, de 2011. Por medio del cual se adopta una política de descentralización educativa a comunas y corregimientos de la ciudad de Medellín de los programas académicos ofrecidos por las Instituciones Universitarias Instituto Tecnológico Metropolitano, Tecnológico Pascual Bravo y Colegio Mayor de Antioquia. Gaceta Oficial, n. 3853, 2011.

ÁrEA METROPOlitana DEL VAlLE DE ABURRÁ. Plan de Gestión 2012-2015 Pura Vida. Medellín: Área Metropolitana del Valle de Aburrá, 2012. ÁREA METROPOLITANA DEL VALLE DE ABURRÁ; CONSEJO METROPOLITANO DE PLANIFICACIÓN. Directrices metropolitanas de ordenamiento territorial: hacia una región de ciudades - Acuerdo Metropolitano no 15, de 2006. Valle de Aburrá: Oficina de Comunicaciones, 2006.

COLOMBIA. Decreto-Ley no 1.333, de 1986. Por el cual se expide el código de régimen municipal. Diario Oficial, n. 37466, 1986.

. Ley no 128, de 1994. Por la cual se expide la Ley Orgánica de las Áreas Metropolitanas. Diario Oficial, n. 41236, 1994.

MELO, J. O. La constitución de 1886. In: MEJÍA, A. T. et al. Nueva historia de Colombia. Bogotá: Editorial Planeta, 1989. 
